\title{
Assertion and Its Many Norms
}

\author{
John N. Williams \\ School of Social Sciences \\ Singapore Management University \\ Level 4, 90 Stamford Road \\ Singapore 178903 \\ johnwilliams@smu.edu.sg
}

\section{Article info}

CDD: 121

Received: 02.05.2017; Accepted: 05.10.2017

DOI: http://dx.doi.org/10.1590/0100-6045.2017.V40N4.JW

Keywords:

Norms

Lies

Assertion

Belief

Speech-acts

\begin{abstract}
Timothy Williamson offers the ordinary practice, the lottery and the Moorean argument for the 'knowledge account' that assertion is the only speech-act that is governed by the single rule that one must know its content. I show that these fail to support it and that the emptiness of the knowledge account renders mysterious why breaking the knowledge rule should be a source of criticism. I argue that focussing exclusively on the sincerity of the speech-act of letting one know engenders a category mistake about the nature of constraints on assertion. After giving an analysis of assertion I propose that the norm of a type of assertion is the epistemic state one needs for one's speech-act to succeed in being an assertion of that type and that the epistemic state in question is determined by the point of the type of assertion. One is practically irrational in violating the norm.
\end{abstract}

\section{Assertion and Its Many Norms}

Timothy Williamson offers the ordinary practice, the lottery and the Moorean argument for the 'knowledge account' that assertion is the only speech-act that is governed by the single 'knowledge rule' or norm, that one must know its content. I show that the emptiness of the knowledge account renders mysterious why breaking the knowledge rule should be a source of criticism. I then argue that focussing exclusively on the sincerity of the speech-act of letting one know engenders a category mistake about the nature of constraints on assertion. For Williamson and those in his tradition, assertion falls under purely

Manuscrito - Rev. Int. Fil. Campinas, v. 40, n. 4, pp. 39-76, out.-dez. 2017. 
epistemic norms. But assertion is an epistemic action and is governed by norms of epistemic action. The action of informing someone is an epistemic action. So is proclaiming one's faith, answering an examiner or lying. I propose that norm of a type of assertion is the epistemic state one needs for one's speech-act to succeed in being an assertion of that type and that the epistemic state in question is determined by the point of the type of assertion. Consequently, much of the knowledge account is at odds with this proposal, although some of it is also correct if assertion is thought of narrowly as informing. Next I show that Williamson's the ordinary practice argument, the lottery argument and the Moorean argument fail to support the knowledge account. After giving an analysis of assertion, I propose that the norm of a type of assertion is the epistemic state one needs for one's speech-act to succeed in being an assertion of that type and that the epistemic state in question is determined by the point of the type of assertion. One is practically irrational in violating the norm.

\section{Williamson's Knowledge Account}

Williamson (2000) tells us that assertion is the only speech-act that is governed by the single rule that one must know its content (2000, 240-241). In this sense the rule is 'constitutive' of the speech-act of assertion (2000, 239, 240-266). This rule is akin to the rule of a game $(2000,239)$. Breaking it does not result in the failure to make an assertion, $(2000,239)$ but makes one subject to criticism $(2000,240)$. One may think of the rule as a norm $(2000,238)$ or as giving the condition on which a speaker has the authority to make an assertion (2000, 257).

Williamson tells us that in articulating the knowledge rule we describe our normal practice of assertion $(2000,253)$ and doing so is like articulating for the first time the rules of a traditional game $(2000,239)$. Ordinary speakers are implicitly sensitive to the rule, for they must have grasped it in mastering assertion (2000, 243).

The knowledge account may be summarized in the slogan 'Only knowledge warrants assertion' where 'warranted' is a term of art that does not mean 'reasonable' $(2000,243)$ but simply means that the assertion complies with the knowledge rule. (2000, 255) Thus one may have excellent evidence for an unwarranted assertion (2000, 254).

A weaker version of the knowledge account (earlier defended by Peter Unger 1975, 253-270 and Michael Slote 1979, 185 and maintained by Keith

Manuscrito - Rev. Int. Fil. Campinas, v. 40, n. 4, pp. 39-76, out.-dez. 2017. 
DeRose 2002, 179), is that to assert that $p$ is to represent oneself as knowing that $p$. Call this the 'representation account'. Williamson (2000, 252, $n 6)$ argues that this is subsumed by his knowledge account, since in doing anything for which authority is required, one represents oneself as having the authority to do it and to have the authority to assert that $p$ is to know that $p$.

Williamson offers three arguments for the knowledge account, namely the ordinary practice argument, the lottery argument and the Moorean argument. First I turn to the emptiness of the knowledge account and the category mistake that this engenders, namely misconceiving of assertion as falling under purely epistemic norms.

\section{The Emptiness of the Knowledge Account: What's Wrong with Breaking the Rule?}

Williamson says more about what the norm of assertion isn't than what it is. He tells us that constitutive rules are not necessary conditions for performing the constituted act $(2000,240)$. He says nothing about what the necessary and sufficient conditions of the speech-act of assertion might be. He gives few examples of assertion, although he does observe that assertions are not verbal conjectures (2000, 244-245).

Moreover, the assertions that are supposed to be held up to the knowledge rule are restricted to 'flat-out' or 'outright unqualified' assertion (Williamson 2000, 246). But aren't qualified assertions such as 'He is, I think, a keen cyclist' still assertions nonetheless? If so, then the knowledge account is incomplete. It doesn't account for all assertions.

Those who follow Williamson in discussing norms of assertion likewise give no account of the nature of assertion. ${ }^{1}$ I will fill this lacuna in section 9. Yet surely we are in no position to decide what the norm of assertion is, or even if there is one, until we first know what assertion is supposed to be. The single clue Williamson gives us is his pronouncement that assertion is the 'exterior analogue of judgement' $(2000,238)$ and that 'occurrently believing $p$ stands to asserting $p$ as the inner stands to the outer' $(2000,255)$.

\footnotetext{
1 This includes those that oppose it, such as Maitra and Weatherson 2010, Weiner, 2005, Brown 2010, Douven 2006, Hill and Schechter 2007 Kvanvig 2009 and 2011, Lackey 2007 and 2008 as well as those who defend it such as Benton 2011 and 2012, Turri 2010b and Blauuw 2012.
}

Manuscrito - Rev. Int. Fil. Campinas, v. 40, n. 4, pp. 39-76, out.dez. 2017. 
This might lead us to think that if I judge that it is raining, then uttering to you the words 'It is raining' is the exterior analogue of my judgement and so is an assertion. This cannot be correct however, since I might utter these words in order to test a microphone or as lines in a play, in which latter case I at most merely depict the speech-act of assertion. Nor does assertion require utterance. There are non-verbal assertions. Suppose that you ask me whether the trains are running and I respond by nodding my head in emphatic affirmation. I have asserted that they are running. So in the ordinary sense of the word, asserting isn't saying (contrary to Herman Cappelen 2011). Nonetheless it will be convenient to retain the application of the term 'speech act' to assertions, bearing in mind that the act may be non-verbal.

More importantly, if one's assertion is the exterior analogue of one's judgement, then since there is no such thing as an insincere judgement, assertions are necessarily sincere. This result coheres with Williamson's preoccupation with the point of assertion as informing. He seems to think of making an assertion as restricted to letting one know (or equivalently, 'informing' one). This is why he claims that 'We need assertion to transmit knowledge' (2000, 267). For example, if you ask me the time, I may let you know that it is 2 pm by asserting to you 'It is 2 pm'. Of course informing, as opposed to misinforming, is necessarily sincere.

But surely we do make insincere assertions. Lies are perfectly genuine speech-acts of assertion. After all, according to the ordinary usage of words among ordinary folk, if lying is not telling, then we cannot tell lies, and telling must be asserting, otherwise I could not properly tell you the time. My lie to you that it is $2 \mathrm{pm}$, told when I believe or know that it is $3 \mathrm{pm}$, is an assertion. ${ }^{2}$ A seminar that succeeds in teaching people to be more assertive need not make them more sincere. A liar pretends to inform one of a truth but it does not follow that he pretends to assert. Although he is not genuine (in the sense that he is not sincere) his lie is still a genuine assertion. Now if there is only one rule of assertion, namely that one must know its content, then any type of assertion

\footnotetext{
${ }^{2}$ David Rosenthal claims that lies are not genuine assertions but are rather bits of playacting $(1995,208, \mathrm{n} 15)$ and that insincere speech is 'pretend speech' (2010, 25). But then it would follow that I could refute the accusation that I have told you a lie by merely admitting that I was lying, for then I could not have told you anything. In contrast, a genuine case of pretending to speak arises when I utter nonsense that vaguely sounds like Russian in order to make you laugh.
}

Manuscrito - Rev. Int. Fil. Campinas, v. 40, n. 4, pp. 39-76, out.de\%. 2017. 
must be governed by that rule. In particular, since lying is asserting, then in telling you a lie I must know that its content is true. This makes any lie a defective assertion quite independently of any moral criticism, for when I lie to you I believe that what I have told you is false. So unless I am irrational in having contradictory beliefs, I do not believe, nor therefore know, that the content of my assertion is true. Indeed I may easily know that I do not know that it is true.

Moreover, mastering the speech-act of lying does not require implicitly grasping the rule that one knows its content. Indeed if one took this as the rule, then it is difficult to see how one could ever learn to lie.

On the knowledge account, if you criticise me for breaking the knowledge rule in telling a lie, then you are not thereby criticising me for having attempted to deceive you into coming to believe a falsehood. The criticism seems rather to amount to the accusation that instead of telling you a lie I should have informed you of something instead—rather as if I should be playing a different game with different rules.

Williamson and his followers would no doubt insist that insincere assertions are indeed defective. ${ }^{3}$ But the sense in which is so is very empty indeed on his account. He says nothing about the nature of the criticism to which one is subject in breaking the knowledge rule, which is not supposed to be moral or teleological and is not supposed to be incompatible with the aim of one's assertion (2000, 240), or as one might put it, its point. On the knowledge account, defective assertions have no 'warrant' or 'authority', but Williamson has stipulated this to mean only that one has asserted what one does not know, which still leaves us in the dark about why breaking the knowledge rule is a source of criticism. Moreover 'authority' here seems to mean 'authority to accept one's testimony'. But it is part of our ordinary practice of assertion that we very often accept the word of a testifier while fully aware that we don't know that she knows what she says and might suspect that she doesn't know, on the evidence or presumption that she has good enough reasons. We might say for example 'Since she said so, that's good enough for me'.

The only inkling Williamson provides of the nature of the criticism to which someone is subject in breaking the knowledge rule is that he has 'cheated' if he

${ }^{3}$ For example, Kvanvig claims that 'no one is entitled to assert a claim insincerely' $(2009,156)$. The elusive non-moral notion here is 'entitled'.

Manuscrito - Rev. Int. Fil. Campinas, v. 40, n. 4, pp. 39-76, out.-dez. 2017. 
'knowingly asserts a falsehood' (2000, 238, my italics), or makes an assertion when he 'knows that he lacks the requisite knowledge, even though he has a reasonable belief' (2000, 259, my italics). This explanation is at best incomplete. Given our ordinary usage of 'cheat', one cheats at a game only if one breaks a rule while knowing that one has broken it, as Williamson appears to acknowledge. But if believe justifiably but mistakenly that I know that $p$, then I have not broken the knowledge rule while knowing that I have done so, and hence I have not cheated. Thus we are still owed an explanation of why breaking the rule in such cases should be a source of criticism. In any case, it would still need to be shown that assertion is governed only by the knowledge rule, and why one is a fault in breaking it. This hasn't been shown.

The upshot of all this is that the nature of the criticism to which one is subject in breaking the knowledge rule remains utterly elusive. Therefore we are not justified in thinking that breaking the knowledge rule is a source of criticism. After all, if we can't say what the source of criticism is, why should we think that there is any source?

Indeed one might be forgiven for wondering whether Williamson and those in his tradition are really talking of assertion at all, rather than of belief. Williamson maintains that 'one's evidence [for one's belief] is just what one knows' $(2000,251)$ and that there is a 'rule that one should judge (or believe $p$ ) only if one knows $p$ ' $(2000,11)$. It seems then that he would agree that having 'warranted belief' is equivalent to knowing what one believes. But if so, then since one has warrant to believe that $p$ just in case one has warrant to assert that $p$, and one has warrant to assert that $p$ just in case one knows that $p$, it follows that an equivalent statement of the knowledge account is that one has warrant to believe that $p$ just in case one knows that $p$, with the result that the notion of assertion drops out of the picture.

The term 'speech-act' is apt to mislead us. Speech acts are not just acts but also actions, namely acts that one performs intentionally. ${ }^{4}$ Asserting is not like blinking in response to a gnat flying into one's eye. Muttering 'the trains are still running' in one's sleep isn't asserting. Thus there is an important disanalogy between assertion and occurrent belief. On seeing a green leaf under ordinary circumstances, I cannot help believing that the leaf is green. In contrast, unless

\footnotetext{
${ }^{4}$ One might insist that acts are always deliberate. If so, then the term 'act' may simply be substituted for what I call an action.
}

Manuscrito - Rev. Int. Fil. Campinas, v. 40, n. 4, pp. 39-76, out.dez. 2017. 
I am suffering from a psychological compulsion, the assertions I make are always those I could have decided not to make. We should admit that in judging the truth of a matter, there is a sense in which one is 'deciding what to believe'. Peering at two trees in the distance I might wonder which is tallest, and then make up my mind that it is the one on the left. But we may as well say that my mind is made up for me. I do not to choose to believe that the tree on the left is tallest in the way I chose to tell you that the trains are still running.

\section{The Category Mistake of the Knowledge Account}

This exclusive focus on the sincerity of the speech-act of letting one know engenders a category mistake about the nature of epistemic constraints such as Williamson's 'warrant' as it applies to assertion. To recognize this, we must first distinguish the rationality of action from that of belief. The rationality of a belief may be seen as that property of it, if true and not Gettierized, needed for it to be knowledge. ${ }^{5}$ Call this the 'epistemic' rationality of belief.

In contrast, the rationality of an action may be seen as one's acting in a way that an epistemically rational believer, similarly placed, would believe best promotes one's interests by satisfying one's desires and fulfilling one's intentions. Call this 'practical' rationality. For example, going to a shop to buy bread in the knowledge that it is shut is irrational in this sense. So is attempting to cross the Sahara desert on foot without water.

The practical rationality of one's belief would be a matter of how well one's acquisition or maintenance of it best promotes one's interests-as would be judged by an epistemically rational believer, similarly placed-by satisfying one's desires and fulfilling one's intentions. When in a strange town it might be rational in this sense to believe that there is at least one stranger who may be trusted, even on flimsy evidence. ${ }^{6}$ On the other side of the same coin, it might

\footnotetext{
${ }^{5}$ As Williamson would admit $(2000,30)$, this way of seeing it is consistent with his own view of knowledge as the most general mental factive state that is otherwise unanalyzable (2000, 33-48).

${ }^{6}$ In other cases the chance that the content of one's belief is true, something that would benefit one, is raised by one's acquiring or maintaining it. For example, when
}

Manuscrito - Rev. Int. Fil. Campinas, v. 40, n. 4, pp. 39-76, out.-dez. 2017. 
be practically irrational of me to believe that any decision I make will probably turn out badly, despite excellent inductive evidence for this, because I should recognize that clinging to this belief robs me of the ability to make any decision at all, a worse outcome than making generally bad ones. This is not the sort of constraint on belief germane to the Williamson tradition.

Since assertion is an action, namely a deliberate or intentional act, it is subject to the constraints of practical rationally. It is governed by norms of action, in other words practical norms. This is entirely consistent with the fact the action of assertion is also epistemic, such as informing or lying. This is supported by one of Williamson's rare examples of an assertion in which

I shout 'That is your train', knowing that I do not know that it is, because it probably is and you have only moments to catch it" (2000, 256).

Williamson continues as follows.

Such cases do not show that the knowledge rule is not the rule of assertion. They merely show that it can be overridden by other norms not specific to assertion $(2000,256)$

but since assertion is governed by norms of action, there can be no such thing as a purely epistemic norm of assertion. Rather there are practical epistemic norms of assertion. Must there only be one of these, namely that one knows the content of one's assertion? No, because what norms are in play will depend upon what one is trying to do with the assertion. One might aim to impart knowledge (as in teaching, informing or confessing). But one might also aim to report belief (as in opining), conviction (as in proclaiming faith) or knowledge (as in answering an examiner) to instil disbelief (as in eristic assertion) or to deceive one into accepting a falsehood (as in lying). ${ }^{7}$ I will return to this crucial point again in section 9 .

faced with a would-be mugger, my belief that he will not take my wallet might partly spark or sustain my successful resistance to him taking it.

${ }^{7}$ This is in line with an older tradition of discussion of assertion as it relates to Moore's paradox (Baldwin 1990, Jones 1991 Welbourne 1992, Williams 1994) and very broadly in the spirit of Grice (1989) in which the nature of an assertion is more fully explicated in terms of its overall intention or point.

Manuscrito - Rev. Int. Fil. Campinas, v. 40, n. 4, pp. 39-76, out.dez. 2017. 
Examples of assertions that are practically irrational might include, in the right circumstances, attempting to compliment someone by informing him that he is stupid or trying to tell him the lie that $2+2=4$. This is not the sort of constraint that concerns post-Williamson discussants, which is for them, epistemic. $^{8}$

There is also a sense-but only an attenuated and derivative one-in which an assertion may be said to be epistemically rational. If you tell me that it will snow in tomorrow in Bangkok I may judge that this is a silly thing to say, but I do not judge it silly for the same kind of reason that I would judge it silly of you to try to compliment a friend by informing him that he is stupid. Rather, I judge you irrational insofar as I take you to have an epistemically irrational belief, under the assumption — which might be false- that you are sincere. This is the sort of epistemic constraint on assertion that concerns Williamson and those in his tradition. But this is a constraint upon the belief $\mathrm{I}$ have assumed you to have. The constraints of rationality upon the speech-act of assertion are not purely epistemic, as Williamson and his followers assume, but primarily practical.

The two sorts of categories can come apart. One may be practically irrational in asserting that $p$ despite the fact that one's belief that $p$ is epistemically rational. I may have excellent grounds to think that the person I am trying to compliment is stupid. One may also be practically rational in asserting that $p$ despite the fact that one's belief that $p$ is epistemically irrational. Suppose that I have the long-standing belief that people are following me. As my therapist, you bring me to the recognition that my belief is epistemically irrational because I have no reason for it. Nonetheless I find myself unable to discard the belief. So I try to convince you that I still have it for no reason, by telling you 'I still believe that people are following me, although I still have no reason to believe this'. My assertion is practically rational because it furthers the fulfilment of my larger intention of getting you to rid me of my belief.

Conflating the two sorts of constraint is less harmless when asserting is an attempt at informing, for then the speaker genuinely attempts to impart

\footnotetext{
${ }^{8}$ It is clear that Williamson's 'warrant' for an assertion is an epistemic notion, being compliance with the knowledge rule. Likewise Kvanvig, for example, argues that 'to the extent that appropriate assertion is subject to epistemic constraints, those constraints have to do with justification rather than knowledge' $(2009,140)$.
}

Manuscrito - Rev. Int. Fil. Campinas, v. 40, n. 4, pp. 39-76, out.dez. 2017. 
knowledge, and this attempt is subject to both sorts of constraints. One may criticise her for not having the knowledge she thinks she has or because she should see that her larger intention in transmitting knowledge, such as paying a compliment, will not succeed. But for other types of assertion it is important to distinguish the two sorts of constraint. In order to discuss these types, I will propose an analysis of assertion in section 9.

I now turn to Williamson's three arguments for the knowledge account, namely the ordinary practice argument, the lottery argument and the Moorean argument, showing that each fails to support the knowledge account.

\section{The Ordinary Practice Argument and its Supporters}

Williamson claims that our ordinary 'linguistic practice of assertion' (2000, 253) confirms the knowledge account (2000, 243, 252-253). A standard response to one's assertion, say that it is raining, is the question 'How do you know that?' Williamson says that this question presupposes that it has an answer and thus one knows $(2000,252)$. A more aggressive challenge is You don't know that' $(2000,253)$. If the knowledge account were false then these questions would be irrelevant.

Jonathan Kvanvig objects that in response to an assertion such as 'It is raining' it is also appropriate to give a stronger challenge to it by asking 'Are you certain?' and points out that

If the conversational propriety of various questions is an argument in favour of the knowledge account, the propriety of these questions is an argument in favour of a stronger account: that one must be absolutely certain in order for a claim to be assertible $(2009,143$, my italics).

Williamson's defence against this line of objection is that although it is appropriate to assert ' $p$ but by Descartes's standards of certainty I cannot be absolutely certain that $p$ ', 'assertibility goes with knowledge, not the highest possible standards of certainty' (2000, 254).

John Turri $(2010,459)$ observes that Kvanvig may simply evade this defence by noting the propriety of asking 'Are you certain?' in terms of ordinary standards of certainty. Turri instead mounts a different defence. Consider an official at a wedding who utters 'I now pronounce you man and wife'. Turri 
observes that it is appropriate to ask her 'Are you certain that you're allowed to do that?' and claims that this shows that the requisite authority to make the pronouncement, namely being legally licenced, is not her certainty that she is so authorized. By analogy, 'Are you certain?' is a challenge to one's certainty that one has the authority to assert 'It is raining', not to one's authority, namely compliance with the knowledge rule. Thus the propriety of 'Are you certain?' is consistent with the knowledge account $(2010,459)$.

This defence fails for three reasons. Firstly, the analogy is flawed. It works only if it holds between different challenges to assertions, but the pronouncement is not an assertion but only a performative. The utterance of a declarative sentence is performative just in case uttering it, in the right circumstances, brings about a state of affairs other than just its having been uttered. Assertions purport to report the state of the world whereas performatives aim to change it. Some performatives are also assertions. If I say to you in the right circumstances 'I promise that I will be punctual tomorrow' then I have promised to be punctual. But it also seems correct to say that I have asserted that I will be punctual. I have changed the world by bringing into existence a promise, so my utterance is a performative. But I have also reported a future state of affairs of the world, consistently with my utterance being an assertion as well. The official's uttering to a couple in the right circumstances 'I now pronounce you man and wife' marries the couple, so this utterance is a performative. But in contrast to the promise, it does not seem to report a state of the world. There is no need to report the existence of a marriage that has so conspicuously just been brought into existence. Such a report would violate Grice's maxim of quantity by giving more information than is needed (Grice 1989, 26).

Secondly, although a legal licence is required for the pronouncement to authoritatively marry the couple, this does not mean that it does so appropriately. Not every legally licenced performance is appropriate. Having changed my name by deed poll to 'Barack Obama', it would still be inappropriate for me to introduce myself unqualifiedly over the phone with 'I am Barack Obama'. Likewise if the official is legally licenced to marry the couple but is uncertain that she is so licenced (perhaps because she is suffering from dementia), then it would clearly be inappropriate of her to make the pronouncement. 
Thirdly, even if the propriety of 'Are you certain?' is consistent with the knowledge rule, the fact remains that we still have an explanation of the propriety that rivals it.

Turri then claims that the knowledge account explains the propriety. $\mathrm{He}$ argues that by ordinary standards of certainty, if one is certain that $p$ then one knows that one knows that $p$, so to ask someone who asserts that $p$ whether she is certain that $p$ is to ask her whether she knows that she knows that $p$. By asserting that $p$, she represents herself as knowing that $p$. Thus asking her whether she is certain that $p$ amounts to asking her whether she knows that she is accurately representing herself $(2010,459-460)$.

Turri's explanation faces a limitation and two objections. The limitation is that it is not an explanation of how the knowledge account explains the propriety of the stronger challenge, but rather an explanation of how it might be dealt with by the weaker representation account. The notion of representation does not figure in the knowledge account. Moreover Unger and Slote themselves say little about it, which provides no way to evaluate the claim that if one asserts that $p$ then one represents oneself as knowing that $p$. Kvanvig defends this claim on behalf of Williamson as follows. Since the norms of a practice are presupposed by those involved in the practice, hearers expect speakers to know and speakers expect to be taken to know $(2009,144){ }^{9}$

But lying shows that this argument proves too much. If you know that I am a habitual liar when I assert to you that $p$, then you will not expect me to know that $p$, yet surely I am still representing myself to you as knowing that $p$, otherwise I could not sensibly hope that my lie will succeed.

Moreover, I might represent myself as knowing that it is raining by supposing for the sake of argument that I know this, yet no impropriety results if I point out in the process that I do not know that it is raining.

Against Turri's explanation, being certain that $p$ does not entail that one knows that one knows that $p$. I may be as certain as reasonably possible of a falsehood, in which case I do not know that $p$, nor therefore know that I know that $p$. Secondly, asking someone whether she is certain that $p$ is not to ask her whether she knows that she knows that $p$. Surely 'Are you certain that the post office is on Carter Street?' is a different and less complex question from the

\footnotetext{
${ }^{9}$ However there appears to be no textual evidence in Williamson (2000) that this is his argument.
}

Manuscrito - Rev. Int. Fil. Campinas, v. 40, n. 4, pp. 39-76, out.de\%. 2017. 
odd and usual 'Do you know that you know that the post office is on Carter Street?' An appropriate answer to the first, but not the second, would be 'Yes, I'm pretty certain that it is, but I might be mistaken'.

Other supporters of the knowledge account invoke additional conversational data. Turri observes that not only may we challenge an assertion, but we may also prompt someone to make one by asking, for example, "What time is it?' or 'Do you know what time it is?' Turri claims that 'these two prompts are practically interchangeable. Competent speakers respond to them identically' (Turri 2010, 460). We may also abstain from answering a question by saying 'Sorry, I don't know' (Turri 2015, 386).

However we may also prompt an assertion by asking 'What time do you think it is?' and competent speakers also respond to this interchangeably with 'What time is it?' We may also abstain from answering a question by saying 'Sorry, but I can't say', and one explanation of this is that we have no justified belief about what time it is. So the knowledge account fares no better than this alternative explanation of the data.

Matthew Benton (2011) claims that parenthetical assertions such as 'It is, I know, raining' (or 'It's raining, I know') are inappropriate, as explained by the knowledge account, because what one's unqualified assertion that it is raining 'expresses one's knowledge' (Benton 2011, 685), with the result that the parenthetical 'I know' is redundant and thus inappropriate.

Rachael McKinnon and John Turri (2013) give an objection to Benton. Suppose that you and I are playing golf when it starts raining, 'a fact we are both obviously alert to' $(2013,126)$. I say to you, 'Look, it's raining' and you reply appropriately 'It's raining, I know'. However they think that this is not a decisive example against Benton because he could respond that your parenthetical 'I know'

... serves to indicate that my initial assertion was otiose because you already knew that it was raining, in which case the parenthetical is not redundant' $(2013,126)$.

This response would fail. My 'Look, it's raining' might have a point if, for example, I intend to urge you to take action such as putting on a raincoat or retreating to the clubhouse. Here I remind you of the practical importance of what I know you already know. Thus my assertion is governed by a practical epistemic norm. The norm is not entirely epistemic of course, as we saw in 
section 3. How could it be? Assertion is an action, after all, albeit an epistemic action. My assertion is not improper, but its propriety is not to be explained in terms of the knowledge rule but in light of the fact that my assertion has a point other than informing you that it is raining. On the other hand, if my only point is to inform you that it is raining, then my assertion is indeed improper, because I cannot sensibly hope to impart to you knowledge that I know you already have. But in that case the knowledge rule cannot explain the impropriety, because I indeed know that it is raining.

Furthermore, there are cases in which we make parenthetical assertions to a hearer who does not already know its content. Suppose that tell you that Jack is a keen cyclist. You ask if I am sure and I reply 'He is, I know, a keen cyclist'. This reply is perfectly appropriate. So the parenthetical stressed ' $\mathrm{I}$ know' is not redundant, contrary to Benton.

Martijn Blauuw however takes this parenthetical stressed use of 'I know' as evidence in favour of the knowledge account. For example, in response to repeated accusations that I am very lazy, I might reply 'I am, I know, very lazy!' or 'I am very lazy, I know!' Blauuw observes that this is an appropriate assertion.

He claims that this is because the stressed 'I know' reinforces the expression of knowledge (that I am very lazy) made by the outright assertion ('I am very lazy') in which it is embedded. Likewise there is a 'repeated parenthetical' use of 'I know' that is not redundant. For example, 'I am very lazy, I know, I know!' or 'I am, I know, I know, very lazy!' also reinforces the expression of knowledge (that I am very lazy) made by the outright assertion ('I am very lazy') in which it is embedded. In contrast, 'I am very lazy, I believe!' is inappropriate because the parenthetical 'I believe' hedges the assertion in which it is embedded. It reduces my commitment to knowing that I am very lazy to only knowing that I believe that I am very lazy. But the parenthetical 'I know' may reinforce the assertion in which it is embedded by changing me from representing myself as knowing that I am very lazy to representing myself as knowing that I know that I am very lazy $(2012,107)$.

I agree that the stressed or emphatic 'I know!' may express knowledge, as I will explain in section 8. Nonetheless Blauuw's examples are not decisive in favour of the knowledge account for four reasons. Firstly, like Turri (2010), he has defended the representation account while leaving the knowledge account untouched. Secondly, 'I am, I believe, very lazy', sounds inappropriate because that one is very lazy is not the sort of thing that one merely believes, rather than knows. In this respect the assertion is inappropriate in much the same way as 'I

Manuscrito - Rev. Int. Fil. Campinas, v. 40, n. 4, pp. 39-76, out.de\%. 2017. 
am, I believe, very angry' or 'I am, I believe, in much pain'. In contrast 'He is, I believe, a keen cyclist' is perfectly appropriate. Thirdly, it may be argued that it need not only be the stressed 'I know' that expresses knowledge. The verbal counterpart of the exclamation mark may do so as well, as in 'I am very lazy!' or 'He is a keen cyclist!' I will return to this point in section 8. Lastly there is an alternative explanation of why 'I am, I know, very lazy' might be appropriate in way that 'I am, I believe, very lazy' is not. This is that I know that only admitting knowledge of my guilt, in other words, confessing-perhaps repeatedly_will satisfy my accuser and so stop the nagging. In such a case my response is practically rational. In contrast, consider a less demanding accuser who alleges that I spilt coffee on the floor last night. As my memory starts to clear and my hangover recede, I respond ' $\mathrm{Hmm}$... I did, I think, spill it on the floor'. This response might be both sincere and appropriate, especially if I know that she will be satisfied merely by my admission that I believe that I am guilty.

Moreover, the propriety of my assertion 'Jack is a keen cyclist, so I believe' falsifies the knowledge account. There is nothing improper in my assertion that Jack is a keen cyclist. But my parenthetical 'so I believe' conversationally discounts my knowledge that he is a keen cyclist because, as Williamson acknowledges, adding this would be 'conversationally misleading' (2000, 42) were I to know that he is a keen cyclist. In that case I would violate Grice's maxim of quantity by giving you less information than you need $(1989,26)$. Moreover the knowledge account predicts that because my assertion is proper, I know that Jack is a keen cyclist. But if so then my qualification 'so I believe' would be redundant because whatever I know, I already believe. Clearly it isn't redundant.

In sum, our ordinary practice of assertion — or in more old-fashioned terms, appeal to ordinary language-does not substantially support the knowledge account.

\section{The Lottery Argument}

Next consider Williamson's lottery argument (2000, 246). You have bought a ticket in a lottery that I know is fair with many tickets, only one of which wins. The draw has been held but the result has not yet been announced. On

Manuscrito - Rev. Int. Fil. Campinas, v. 40, n. 4, pp. 39-76, out.-dez. 2017. 
the probabilistic grounds that your ticket was only one of many, but without telling you my grounds, I make the unqualified assertion to you 'Your ticket did not win'. Williamson claims that 'Intuitively, [these] grounds are quite inadequate for that outright unqualified assertion' $(2000,246)$. He continues as follows.

You will still be entitled to feel some resentment when you later discover the merely probabilistic grounds for my assertion. I was representing myself to you as having a kind of authority to make the flat-out assertion which in reality I lacked. I was cheating $(2000,246$, my italics)

The knowledge account is supposed to explain the persistence of your entitlement to resentment, since I did not know that your ticket did not win. Thus I have no warrant for my assertion, but only for 'It is highly probable that your ticket did not win'. Nonetheless Williamson admits that I do have excellent evidence that your ticket did not win and also excellent evidence that I do not know that it did not win $(2000,254)$.

This position is objectionable. Firstly, it is far from clear that you were entitled to feel resentment when I first made my assertion. For all you knew, I might have known that your ticket did not win. Nor does my not telling you my grounds for an assertion normally entitle you to feel resentment. If you telephone me to ask whether it is raining in my location and all I tell you is that is raining, I do not entitle you to feel resentment. If you did feel resentment when I told you that your ticket did not win, it was probably because you thought it rude of me to remind you of my misfortune. If so, discovery of the wholly probabilistic grounds for my assertion will not mollify you.

Secondly, let us assume for the sake of argument that I did represent myself to you as having a kind of authority to make the assertion that I lacked. It does not follow that the authority involved is, as Williamson has merely stipulated, my knowledge that your ticket did not win. An alternative explanation is that I represented myself to you as having extra, non-probabilistic evidence not amounting to knowledge that I lacked that would increase the justification of my belief that your ticket did not win by adding it to the merely probabilistic evidence. This might be that I have quickly scanned the results of the lottery in today's newspaper and did not recognize your number, or that I have been told by a generally but not completely reliable testifier that someone else has won. 
Lastly, Williamson has the intuition that although my knowing only that your ticket was one of many is excellent evidence that it did not win, nonetheless it is inadequate for my assertion. This is all that supports his lottery argument. But intuitions vary. My intuition is that because it is excellent evidence, it is indeed adequate and that there is nothing improper in my assertion. I know many ordinary people who use words in ordinary ways and who share my intuition. How do we go about adjudicating which intuition is decisive?

A comparison with a different case might help. Suppose that you acquire the irrational fear that all the molecules of oxygen in the room will suddenly congregate in one corner, resulting in our suffocation. Knowing only that there is roughly one in a googleplex chance that this will occur, I tell you solemnly, 'That won't happen'. My assertion seems quite proper. Indeed it seems improper of me to tell you instead 'That's very unlikely to happen' because that would give you less reassurance than is appropriate. Instilling in you the conviction that it won't happen is the point of my assertion. That I would make the former rather than the latter assertion seems perfectly in line with our ordinary practice of assertion.

In the lottery case, someone such as myself who genuinely believes that probabilistic grounds are authority enough to tell you that your ticket did not win, has not misrepresented himself even if probabilistic grounds are not in fact proper authority. Such a person misrepresents herself as having proper authority only if she believes that she doesn't have it. She does believe she has it.

\section{The Moorean Argument}

Williamson's Moorean argument goes as follows (2000, 253-254). Something is wrong with any assertion of the form ' $p$ and I do not know that $p$ '. The knowledge account explains this by showing that one cannot know it. Supposing for reductio that I do, then since knowing a conjunction involves knowing each conjunct, I know that $p$. But knowing the conjunction also means that both conjuncts are true, hence I don't know that $p$. Thus I do and don't know that $p$. Contradiction. ${ }^{10}$ In contrast, the hypothesis that not only

${ }^{10}$ Sorensen (1988) argues similarly, calling this a 'knowledge blindspot'.

Manuscrito - Rev. Int. Fil. Campinas, v. 40, n. 4, pp. 39-76, out.-dez. 2017. 
knowledge warrants assertion makes it hard to understand why the assertion is improper.

But some assertions of the form ' $p$ and I do not know that $p$ ' are proper. Suppose that you ask me if the trains are running. I reply colloquially, yet properly

'They are running. But don't quote me, I don't know it for a fact'.

My assertion of the first conjunct is both outright and unqualified and so is 'flat-out'. The propriety of my reply derives from the fact that you will recognize its point, which is to instil in you my belief that the trains are running while disclaiming knowledge, and with it the commitment that comes with claiming to have knowledge, should my belief turn out to be false.

Or suppose that I have bought the lottery ticket and the draw is yet to be held. You say to me 'Don't get your hopes up!' I nod my head to show my acceptance of your advice and reply earnestly yet gloomily 'My ticket won't win', thus expressing my conviction that it won't win. My conviction is justified by my knowledge that there is very little chance of it winning. However I don't know that it won't win, since there is nothing to indicate that my ticket is any different from all the others, one of which will win. Furthermore, I'd be silly to buy a ticket that I know won't win and since I know I'm not silly in this way, I know that I don't know that it won't win. In contrast, I may sensibly buy a ticket in the justified conviction that it won't win, because in so doing I am really purchasing the slim chance that my justified conviction may turn out to be false. This might be a good purchase if the cost is low and the reward high.

Suppose that you know all this of me. You hear nothing improper in my non-jocular assertion 'My ticket won't win'. Nor will you hear impropriety if I tell you instead

'My ticket won't win. I'm convinced of that. But still, one never knows'.

By 'one never knows' I include myself of course, as you recognize. You are entitled to take me as both truthful and sincere. You will see the point of my assertion, which is to make a realistically pessimistic prediction tempered with a realistic degree of optimism. 
Kvanvig (2009) gives a rival explanation of the putative impropriety of all Moorean assertions in terms of sincerity and justification for belief. He argues for 'Kvanvig's principle'

If one is justified in believing that $p$ and one knows that one believes that $p$, then one is justified in believing that one knows that $p^{11}$

as well as Kvanvig's norm of sincerity:

One should assert that $\mathrm{p}$ only if one believes that $p$ and Kvanvig's norm of justification:

One should assert that $p$ only if one is justified in believing that $p$.

Now suppose that I assert that ( $p \&$ I don't know that $p$ ). I have asserted that $p$. Given my conformity to the norm of justification, I am justified in believing that $p$, and given my conformity to the norm of sincerity and that I know whether I am sincere, then I know that I believe that $p$. So by Kvanvig's principle, I am justified in believing that I know that $p$. But this means that I am not justified in believing that I do not know that $p$, yet I have also asserted that I do not know that $p$ and so have violated the norm of justification. ${ }^{12}$

However, suppose that you ask me 'Will it rain?' I look up at the sky and seeing dark clouds gathering, assert 'It will rain soon'. I know myself to be a very reliable predictor of rain but I also know that my evidence falls short of that needed for knowledge. Against Kvanvig's principle, I know that I believe that it will rain soon, and I am justified in thinking that it will, but I am not

\footnotetext{
${ }^{11}$ Kvanvig's argument for this principle depends crucially on the claim that a necessary condition of one's knowing that $p$ is that one has justification for one's belief that $p$ that is ultimately undefeated $(2009,145)$. In (Williams 2015) I argue that one should not accept this claim, because it prohibits one from knowing that one has a posteriori knowledge.

${ }^{12}$ Here Kvanvig assumes two other principles, that, plausibly, asserting a conjunction involves asserting its conjuncts, and also that if one has a pair of beliefs the contents of which are in overt contradiction, then one cannot be justified in having both. I defend both principles in (Williams 2010).
}

Manuscrito - Rev. Int. Fil. Campinas, v. 40, n. 4, pp. 39-76, out.dez. 2017. 
justified in believing that I know that it will rain soon. In fact I might know that I don't know this. Knowing all of this of me, it seems that I may properly tell you 'It will rain soon, but I don't know that it will'. Placing stress upon 'know' might properly indicate to you that I regard such matters as beyond our ken.

Let us make this indication more salient. Suppose that I have a particular view of knowledge as requiring sensitive belief. By my lights, I cannot know that it will rain soon, because were it not about to rain soon, I would, on the same basis of seeing dark clouds gathering, still believe that it will. Again from my perspective, I am entirely sensible in trying to secure the best epistemic state available short of knowledge, namely justified conviction that it will rain soon. Supposing that you know my epistemological views on this matter, if you ask me whether it will rain and I reply 'It will rain soon, but I don't know that it will', you will hear no absurdity, even if you do not share my view of knowledge, one of which I remind you by placing stress on 'know'. You will see the point of my assertion, which is to get you to accept my prediction on the strength of my justified conviction.

Matthew Weiner (2005) gives a similar example. Captain Jack Aubrey, who has long experience of naval combat against the French Navy, has been watching French ships maneuver, together with the less experienced Lieutenant Pullings. At 2 pm Aubrey says to Pullings 'The French will attack at nightfall'. Weiner observes that this seems to be a proper assertion, yet Aubrey's grounds are not the sort that would be sufficient for knowledge. He adds that were Pullings to ask 'How do you know that the French will attack at nightfall?' Aubrey might properly reply

I don't know they'll attack at nightfall—we haven't intercepted their orders — but my prediction is that they will. $(2005,238)$

Benton (2012) makes three objections. ${ }^{13}$ His first is that if the knowledge rule does not apply to this case then we should expect that queries such as 'How do you know?', 'which presuppose knowledge' $(2012,104)$ will clearly be inadmissible in response to predictions such as 'The French will attack at nightfall' and they aren't.

${ }^{13}$ I will not deal with these in the order in which Benton gives them.

Manuscrito - Rev. Int. Fil. Campinas, v. 40, n. 4, pp. 39-76, out.de\%. 2017. 
But here we should note, as Williamson acknowledges (2000, 253), that 'How do you know that?' is not always intended as challenge to an assertion but may be a straightforward request for the reasons the speaker has for believing the content of her assertion. Taken that way, Pullings is asking whether Aubrey knows that French will attack at nightfall, by asking him, inter alia, if there is any source of would-be knowledge. Thus the question is admissible, for Pullings has in effect asked Aubrey whether he knows that the French will attack at nightfall and Aubrey has properly and truthfully replied that he does not.

Benton further objects that

'I don't know they'll attack at nightfall but my prediction is that they will'.

is not akin to

'I don't know that they'll attack at nightfall, but they will'

Because

... its final conjunct, prefaced as it is with 'my prediction is that' seems to back off' from the original outright 'The French will attack at nightfall'. (20012: 104).

But there is no backing off. In telling Pullings 'The French will attack at nightfall', Aubrey is already making a prediction, as Pullings well knows. So the prefaced 'my prediction is that' reiterates the prediction.

It might be replied that if one asserts 'They'll attack', then one predicts that they'll attack but if one asserts 'I predict that they'll attack', then one asserts that one predicts that they'll attack. This is perfectly true, but by asserting that one predicts that they'll attack, one also predicts that they'll attack. This is consistent with Williamson's observation $(2000,259)$ that by asserting that one asserts that $p$ (as in 'I'm telling you that they'll attack'), one asserts that $p$, (as in 'They'll attack'). This is why, if Aubrey tells Pullings 'They'll attack' and Pullings asks 'Are you sure?' Aubrey may properly reply 'They'll attack, I tell you'. His 'I tell you' reiterates and thus reinforces his prediction.

Benton's final objection is merely that 'I don't know that they'll attack at nightfall, but they will' 'sounds quite bad' $(2012,103)$. In effect, we have already 
dealt with this point, because Benton neglects to follow Weiner in italicizing 'know'. Aubrey's stress on 'know' may play a crucial role. Suppose that instead of mentioning the interception of orders, Aubrey has already explained to Pullings that although he has undisputed know-how in reading French maneuvers with great predictive success, the future just isn't the kind of thing we may know. He might have claimed that that the future is unsettled in a way the past isn't or that there are no truths about the future or that only God may know what the future will bring. The following conversation might ensue.

Aubrey: The French will attack at nightfall.

Pullings: How do you know?

Aubrey: I don't know that they'll attack at nightfall, but they will.

Aubrey's stress on 'know' is his reminder to Pullings that by his lights, knowledge of a future attack has already been ruled out, with the result that the attempt to obtain it is inappropriate. Even if Pullings disagrees with Aubrey's view of the future, still he cannot appropriately look to Aubrey for knowledge, but as a practical lad in a dire situation should be prepared to settle for something less, like Aubrey's word (as in his 'I tell you') or his justified conviction. Thus instead of the conversation above, it would also be appropriate of Aubrey to remark

'The French will attack at nightfall. Of course that isn't the sort of thing one may know. But still I'm convinced that they'll attack'.

In both cases Pullings (and you, the reader) will see the point of Aubrey's assertion, which is to instil belief or conviction in Pullings that the French will attack at nightfall.

It is not only predictions that may be properly conjoined with a denial of knowledge. Suppose that I wish to join a fideistic religious order that holds that the existence of God is an article of faith, His existence being unknowable. To show that I am eligible to join, I assert to the relevant patriarch

'God exists. My faith in that is unshakable, but of course the existence of God isn't the sort of thing one may know'. 
The patriarch will hear nothing improper, especially if he follows Luther in holding that knowledge of God's existence would exclude faith in it. ${ }^{14}$ Knowing all this, you will not detect impropriety either, since whatever your religious beliefs, you will recognize the point of my assertion, which is to affirm my allegiance to the doctrine by my proclamation of faith.

\section{The Impropriety of Some Moorean Assertions}

In sum, not all assertions of the form ' $p$ and I don't know that $p$ ' are improper. But others are indeed improper. Moore remarks that it is 'absurd' to

'... assert "Dogs bark, but I don't know that they do" ... because by asserting $p$ positively you imply, though you don't assert, that you know that $p^{\prime}(1962,277)$.

But the absurdity here derives not from the knowledge rule but from the fact that it is common knowledge that dogs bark, with the result that 'I don't know that they do', sounds transparently insincere and thus inappropriate. A better example not involving common knowledge is that of a chemistry teacher who teaching her pupils facts about elements, tells them 'Lithium is an alkali metal'. She is informing her pupils, in other words letting them know, that this is so and the point of her assertion is to transmit her knowledge to them. If she now adds in the same breath 'but I don't know that lithium is an alkali metal', then her conjunctive assertion is 'absurd'.

The same is true of non-verbal assertions. Suppose that you ask me whether the trains are running and I respond by nodding my head in emphatic affirmation while holding up my thumb as a kind of semiotic exclamation mark. I have asserted that the trains are still running. Suppose also that you know me well enough to recognize that I behave in this way only when I take myself to know what I am affirming. Then you will see that I am trying to let you know

\footnotetext{
14 'All the articles of our Christian faith, which God has revealed to us in His Word, are in presence of reason sheerly impossible, absurd, and false' (Luther, Werke viii). We need reason for knowledge of God's existence and the existence of God is an article of faith.
} 
that the trains are still running. If instead I respond with the same behaviour while telling you 'No, they aren't still running' then my assertion is likewise improper.

In contrast, consider a modification of Wittgenstein's (1980, \S 486-487) example with 'know' in place of 'believe', namely that of a railway official who under duress, as you know, announces 'The train will arrive at 5 pm' and then adds the aside to you 'but personally, I don't know that'. You hear no absurdity.

In contrast again, suppose that instead of asking me 'Will it rain?' you ask me 'Do you think it will rain?' and I reply 'It will rain but I don't believe that it will'. My assertion is absurd. This is Moore's omissive paradox, so-called because I assert my specific omission of true belief. ${ }^{15}$ We will return to this in section 10.

How should we explain the fact that some assertions of the form ' $p$ but I don't know that $p$ ' are proper while others are not? The short answer is that when asserting is informing, then the knowledge rule does apply and it is a genuine criticism of one's would-be informant that she does not know what she has told one. I will elaborate on this in section 10.

In the section after next I will propose an analysis of assertion. This requires an analysis of expressing belief, conviction or knowledge, to which I now turn.

\section{Expressing Belief, Conviction or Knowledge}

I will use 'express' as both factive and intentional. It is factive in the sense that where $\mathrm{N}$ is noun phrase such as 'belief', 'knowledge', 'fear', or 'interest', then one expresses $\mathrm{N}$ only if one has $\mathrm{N}$. It is intentional in the sense that one expresses $\mathrm{N}$ only if one does so deliberately. This usage of 'express' is true to its

\footnotetext{
${ }^{15}$ Moore's own example is 'I went to the pictures last Tuesday but I don't believe that I did' (1942, 543) which may be formalized as ' $p$ and I don't believe that $p$ '. Elsewhere he gives a second example, 'I believe that he has gone out, but he has not' $(1944,204)$ which may be formalized as ' $p$ and I believe that not- $p$ '. This may be called the 'commissive' form because I assert my specific mistake in belief. Roy Sorensen (1988) coins these useful labels although I was the first to draw attention to this difference between the forms, which stems from that between atheists and agnostics (Williams 1979).
} 
Latin root 'press out', as in 'She expressed milk from her breast' or 'He expressed the oil of the hop'. One cannot express milk from one's breast unless one has milk in one's breast. Nor may one express oil from the hop unless one presses the hop deliberately.

'Manifest' is also factive. One manifests $\mathrm{N}$ only if one has it. Expressing N involves ostensibly manifesting it. The converse need not hold, either because one does not have N, or because one has not manifested it deliberately. As the first of these two cases, suppose that you ask me for the umpteenth time if I would like to see your holiday snapshots again. I reply untruthfully 'I'd love to see them again'. I have no interest in seeing your snapshots. I have not manifested interest but have only ostensibly done so. Thus I have not expressed interest but have only purported to do so. As the second kind of case, suppose that as a plane takes off I involuntarily begin to sweat profusely, grip my arm-rest until my knuckles are white and adopt a look of terror. I am in fact frightened, but I think that no one is observing me and I do not wish to call attention to myself. I have manifested my fear (and ipso facto have ostensibly manifested it as well) but I have not expressed it, because I have not manifested it deliberately. If unbeknownst to me, you are observing me, I have afforded you a reason to think that $\mathrm{I}$ am frightened, but $\mathrm{I}$ have not offered you a reason to think so. In other words, I have not intentionally afforded you a reason to think that I am frightened.

Applying this account of expression to belief, expressing a belief likewise involves ostensibly manifesting it, but not always conversely. Knowing that you are watching me, I might carry an umbrella in order to deceive you into thinking mistakenly that I believe that it will rain. I have not manifested a belief that it will rain but have only done so ostensibly. So I have not expressed this belief but have only purported to do so. As the case in which I do have the belief, suppose that I believe that my son will return from Brunei tomorrow. Repeatedly muttering in my sleep 'He'll be back from Brunei tomorrow' might afford you reason to think that I believe that he will return from Brunei tomorrow. If I have then belief then I have manifested it. But I have not manifested it to you deliberately, so I have not expressed it to you. In contrast, if you contradict my forecast of rain, I may express my belief that it will rain by defiantly shaking my umbrella in your face, because then I intentionally afford you a reason, in other words offer you one, to think that I believe that it will rain. If I am sincere then I have manifested my belief that it will rain, otherwise I have only ostensibly manifested it. 
This account of expressing belief coheres with the more general idea that one purports to express a propositional attitude to someone just in case one offers her reason to think that one has that attitude. For example, as we take off in a plane I might purport to express fear to you by telling you 'I am afraid that we will crash'. If my assertion is sincere and I really do have that fear, then I have expressed my fear. Or I might silently pat my heart while displaying to you a facial expression of terror. If my performance is insincere, then I have not expressed fear but have only purported to express it.

In the light of all this, Expressing Belief is plausible:

One purports to express to one's actual or potential interlocutors a belief that $p$ just in case one offers them reason to think that one believes that $p$.

Accordingly, one expresses a belief just in case one purports to express a belief that one really does express, and so has that belief. The converse does not hold. My offer of a reason to think that I believe what I assert is defeasible, because you may have grounds for thinking that I am insincere. We will see shortly the need for the qualification 'or potential interlocutors'.

Turning to verbal expressions of belief, a prime way to purport to express a belief is to assert its content, since in making an assertion I present it as evidence that I believe what I have asserted, and so offer you a reason to think that I believe this. This is because there must be a general presumption of sincerity, or else the practice of insincerity could not succeed, since practitioners of deception present themselves as sincere. Thus when I make an assertion to you it is practically rational of you to assume that I am sincere unless observation suggests otherwise.

A clue to how one might express knowledge may be gleaned by revisiting Moore's remark that 'by asserting $p$ positively you imply, though you don't assert, that you know that $p^{\prime}(1962,277$, my italics). Moore nowhere elucidates this sense of 'positively assert' but he might mean something like 'emphatically assert'. Thus if you ask me whether the trains are still running and I nod my head in emphatic affirmation while holding up my thumb, this counts as an emphatic assertion. So does my insistent 'The trains are still running!' said to you as I fix you with a steely look and bang my fist on the table. Here the verbal or counterpart of the exclamation mark plays an important role, as it did in Blauuw's example 'I am very lazy!' 
In ordinary life ones interlocutors take this kind of emphatic behaviour to be ones ostensible signal of ones degree of conviction, or psychological certainty, that one's assertion is true. When we ostensibly signal a very high degree of conviction, those around us tend naturally to take us to know what we assert. When we ostensibly signal a lesser degree of conviction, those around us tend naturally to take us to be convinced of what we assert. If we are sincere, and this is what we have on offer, then we will have expressed conviction. This suggests the following.

E1 If one asserts that $p$, then one purports to express belief or conviction that $\mathrm{p}$

In other cases such as the teacher who tells her pupils that lithium is an alkali metal, it seems to be the context that makes the assertion express knowledge. This is that the pupils know that the teacher is supposed to know what she tells them. This suggests the following,

E2 If one asserts that $p$ in the right way or in the right circumstances, then one purports to express knowledge that $p$.

$\mathrm{E} 1$ is consistent with E2. And so are their consequents.

Of course emphatic assertors, as well as the chemistry teacher, may not in fact have the conviction or knowledge that they purport to express. So modelling the expression of knowledge upon that of belief gives us Expressing Conviction or Knowledge:

One purports to express to one's actual or potential interlocutors, conviction or knowledge that $p$, just in case one offers them reason to think that one is convinced or knows that $p$.

Accordingly, one expresses conviction or knowledge just in case one purports to express conviction or knowledge that one really does express, and so has that conviction or knowledge, although not always conversely.

A second and more direct way to express belief, conviction or knowledge via assertion is to assert that one has the belief, conviction or knowledge. In other words I may purport to express to you belief, conviction or knowledge that $p$ by telling you that I believe, am convinced or know that $p$. We have 
already seen that in making an assertion I offer you a defeasible reason to think that I am sincere. In normal circumstances we should both recognize that I am the best authority on what mental states I have. So in offering you a defeasible reason to think that am I sincere in asserting that I have belief, conviction or knowledge, I am in effect offering you a reason to think that I indeed have it. Thus if you ask me if it is raining I may express my belief, conviction or knowledge that it is, by simply answering 'I believe so', 'I'm convinced that it is' or 'I know that it is'. ${ }^{16}$ This suggests

E3 If one asserts that one believes, is convinced, or knows that $p$, then one purports to express belief, conviction or knowledge that $p$.

Since a reason to think that one knows that $p$ is a reason to think that one believes that $p$, it follows that if one expresses or purports to express knowledge then one expresses or purports to express belief, although not always conversely.

\section{An Analysis of Assertion}

I now propose an Analysis of Assertion:

One asserts that $p$ to one's actual or potential interlocutors, just in case one purports to express belief, conviction or knowledge that $p$ to them with the intention of changing their beliefs or knowledge in a relevant way.

On this analysis, non-reflexive intention is doubly involved in assertion, first in expressing belief, conviction or knowledge, and then in the overall aim of the assertion.

The mention of purported expression accommodates lies, which are surely genuine assertions. Non-verbal assertions are also accommodated, because

16 Rosenthal $(1995,199)$ argues against the conclusion of this simple argument. In (Williams 2013, 1125-1126) I give reasons why his argument fails.

Manuscrito - Rev. Int. Fil. Campinas, v. 40, n. 4, pp. 39-76, out.-dez. 2017. 
shaking my umbrella in your face offers you reason to think that I believe that it will rain.

The analysis explains why muttering in my sleep 'He'll be back from Brunei tomorrow' is not an assertion. I have not deliberately offered you a reason to think that I believe that he will return from Brunei tomorrow, so I have not expressed a belief that he will.

The analysis also explains why you hear no impropriety in the railway announcement. Since you know that she is under orders, in uttering 'The train will arrive at 5 pm' she does not offer you reason to think that she believes that it will arrive at $5 \mathrm{pm}$. So she has not asserted that it will. In addition it explains why the official who utters 'I now pronounce you man and wife' makes no assertion, because it is positively bizarre to think that in so doing he is offering the couple a reason to think that he believes or knows that he is marrying them. In contrast, my utterance 'I promise to be punctual' counts as an assertion as well as a performative, since I aim to convince you that that I will be punctual by expressing my conviction or knowledge that I will indeed be punctual.

The analysis also accommodates the idea that in making an assertion one is thereby committed in some sense to its content. In asserting that $p$, one offers one's interlocutor reason to think that one assents to the proposition $p$. When one asserts that $p$ so as to purport to express conviction that $p$, then one's commitment deepens because then one offers her reason to think that one is confident that one possesses the truth that $p$. When one asserts that $p$ so as to purport to express knowledge that $p$, then one's commitment deepens again, because then one offers her reason to think that one is indeed in possession of the truth that $p$.

The change in the beliefs or knowledge that one intends to bring about is 'relevant' in the sense that the proposition that one asserts forms the core of the description of that intended change. We may describe this intended change as informing, as in teaching or confessing, reporting belief or conviction, as in proclaiming one's faith, reporting knowledge, as in answering an examiner, instilling disbelief, perhaps eristically, and as instilling false belief, as in lying. What type of assertion one makes is therefore partly determined by one's overall intention and success in making that type of assertion is success in fulfilling it. One's interlocutor may not always know the epistemic intention of one's assertion, especially when asserting is lying, but usually the context of assertion will make this clear to her. 
For example, in informing or teaching you that lithium is an alkali metal, I intend to impart to you my knowledge that it is. In confessing to you that I spilled coffee I intend to let you know that I know that I spilled it, thus admitting guilt.

It is worth noting that on this account, one may transmit knowledge to someone without informing her (or equivalently, without letting her know). I might inform someone that the trains are still running without noticing that you are nearby. Overhearing my assertion, and knowing that I am a reliable testifier on such matters, you also come to know that the trains are still running. My knowledge has spread to you, but I have not informed you that the trains are still running - or equivalently, not let you know that this is so. I did not offer you reason to think that believe or know that the trains are still running. I made no assertion to you.

Another type of assertion is opining, in other words, giving one's opinion. Suppose that you ask me 'Do you think it will rain soon?' and I answer 'Yes'. My intention is to let you know that I believe that it will rain soon. We might say that I have made the qualified assertion that it will rain soon. Or I might proclaim my faith in God by telling you 'God exists. My faith in that is unshakable'.

In a case in which I am asked by an examiner what the capital of Thailand is, it is practically wise of me to presume that she knows the answer. In answering 'Bangkok' my aim should not be to inform her that the capital of Thailand is Bangkok, but to inform her that I know that it is.

Next consider eristic assertion. Suppose that I share your belief, conviction or knowledge that heroin is addictive and I know that you will not easily change your mind. Nonetheless I tell you that heroin is not addictive. My larger aim is, as some British folk might say colloquially, to 'wind you up' or 'rattle your cage' by making you think mistakenly that we are divided in belief.

In lying to you that $p$ I intend to make you mistakenly believe that $p$. For example, you ask me the time and looking at my watch I see that it is $3 \mathrm{pm}$. I tell you 'It is $2 \mathrm{pm}$ ' with the intention of making you believe that it is $2 \mathrm{pm} .{ }^{17}$

\footnotetext{
${ }^{17}$ Let us call this the strong sense of 'lie'. Moore objects to this definition saying that

... it is not clearly self-contradictory to say: "What he said happened to be true, but nevertheless he was lying when he said it, for he fully believed it to be false and yet wished to persuade others that it was true"”(1962, 381).
}

Manuscrito - Rev. Int. Fil. Campinas, v. 40, n. 4, pp. 39-76, out.dez. 2017. 
At the time of asserting, the aim of the assertor is to succeed in fulfilling these various intentions. But fulfilling them need not always be practically rational, if success conflicts with other demands of practical rationality. To adapt a previous case, I might successfully inform someone that he has made a silly mistake, but fail in my larger attempt to thereby compliment him. It might be practically unwise of me to inform you that the drunk sitting next to us is likely to react violently when called a drunk if I can see that he is listening intently to our conversation and I wish to avoid altercation. These complications are beyond the scope of my paper.

The clause 'or of a potential audience' is needed to accommodate cases such as the following. Suppose that I am brought before a judge who happens to know me very well. Under oath I tell her 'I live on Carter Street'. I know that she already knows that I live on Carter Street and also knows that I am sincere. So I need have no intention to change her knowledge or beliefs in any way via my assertion. But a central point of testimony under oath is to put it public record so that any interested party may witness it. My intention is surely that such a person will believe that I live on Carter Street or at least will think that I believe it. Likewise if I flourish a billboard proclaiming 'The end of the world is at hand', that counts as an assertion even in an empty street, because I intend to change the epistemic cognition of anyone who might notice.

What of cases in which I appear to make assertions to myself? Suppose that knowing that I tend to leave my hard drive in my office, I say repeatedly to myself aloud as I am getting ready to leave, 'I must take my drive. I must take my drive'. Surely I am not offering myself a reason to think that I believe or know the contents of what I am saying. However it is not clear that my utterances do really count as assertions. It seems plausible that I am repeatedly depicting an assertion to an imaginary interlocutor-perhaps my alter ego- as a theatrical way of reminding myself that I must take my drive.

This fits the sense of 'lie' in which I lie to you that $p$ just in case I assert that $p$ to you with the intention of deceiving you into mistakenly believing that $p$. If unbeknownst to me, my watch is an hour fast with the result that my assertion is true, then Moore would still count this as a lie. Let us call this the weak sense of 'lie', since it is included by, but does not include, the strong sense. In either sense I am insincere in my assertion because I cannot aim to make you mistakenly believe that $p$ via my assertion that $p$ unless I myself believe that not- $p$.

Manuscrito - Rev. Int. Fil. Campinas, v. 40, n. 4, pp. 39-76, out.-dez. 2017. 


\section{Explaining the Propriety or Impropriety of Assertions}

This analysis of assertion helps to explain the propriety or impropriety of assertions we have discussed. I will deal with them in the order that they have appeared.

In telling you ' $\mathrm{He}$ is, I believe, a keen cyclist' or ' $\mathrm{He}$ is, I know, a keen cyclist' I may properly express to you, via E3, my belief or knowledge that he is a keen cyclist in order to instil it in you.

Next consider my reply to your question whether the trains are running,

'They are running. But don't quote me, I don't know it for a fact'.

I have admitted that I do not know the answer and so have avoided the deepest commitment to the truth of my assertion of the first conjunct. This makes my 'But don't quote me' appropriate. By asserting my first conjunct, I have expressed, via E1, my belief that the trains are running in order to instil that belief in you. So I have embraced the shallowest commitment to the truth of my assertion of the first conjunct. This retreat in commitment is appropriate given that getting you to accept my opinion is the best next option available to me to transmitting knowledge.

Next is the case in which I respond to your fear that the molecules of oxygen in our room will suddenly congregate in one corner with

'That won't happen'.

E3 allows me to express my conviction to you that your fear will be unrealized. This conforms to the point of my assertion, which is to give you as much reassurance as is appropriate by transmitting my conviction in your safety to you.

Next consider my confession

'I am, I know, very lazy!'

By E3 I properly let you know that I know that I am very lazy by expressing my knowledge that I am. In contrast, consider my response to your accusation that I spilled coffee, 
'Hmm ... I did, I think, spill it'.

This is not enough to amount to a confession, but is properly enough to satisfy you in admitting only that I think I am guilty by expressing my belief, via E3, that I spilled the coffee.

Next, consider the case in which I respond to your advice to not hope too much from my lottery ticket, with

'My ticket won't win. I'm convinced of that. But still, one never knows'.

My response is appropriate because I express my belief that my ticket will lose via E1 by asserting my first conjunct and then reinforce this by expressing my conviction of this via E3 by asserting my second conjunct. The point of this is to convey to you my pessimism that I temper with a degree of optimism that I assert in my third conjunct.

In telling you 'It will rain soon, but I don't know that it will', I remind you that, by my epistemological lights, I do not know that it will rain, which makes my expression of belief that it will rain (via E1 by asserting my first conjunct) appropriate in the face of this reminder. I tell you this with the intention of getting you to accept my prediction on the strength of my justified conviction.

Next consider the case in which I tell my patriarch

'God exists. My faith in that is unshakable, but of course the existence of God isn't the sort of thing one may know'.

In asserting my first conjunct I express, via E1, my belief in the existence of God, which I reinforce, via E3, by asserting my second. This is appropriately conjoined with my assertion of the third conjunct, by which I express, via E1, my belief that the existence of God is unknowable. The point of my whole assertion is to proclaim what I know is a central feature of my faith.

In contrast, my assertion 'Lithium is an alkali metal but I don't know that it is' said to you as a teacher or when I assert its first conjunct emphatically, is inappropriate. This is because in asserting my first conjunct, I purport to express to you, via E1, my knowledge that lithium is an alkali metal, yet I tell you in the same breath that I do not have the knowledge I purport to express. If you believe what I tell you then you have reason to think that I do not have 
the knowledge that I purport to transmit to you. So the point of my assertion, which is precisely to effect this transmission, must fail. Since I am in a position to see this, on my charitable presumption that you are epistemically rational, it is practically irrational of me to make the conjunctive assertion.

In comparison, consider the case in which I tell my psychiatrist

'I still believe that people are following me, although I still have no reason to think so'.

By asserting my first conjunct I express to her, via E1, my belief, and then tell her that I have no reason for it, which lets her know that I still have it irrationally. Doing so is appropriate because it is part of my practically rational attempt to obtain epistemic damage control.

Finally, consider the case of Moore's omissive paradox in which you ask me 'Do you think it will rain?' and I reply 'It will rain but I don't believe that it will'. By asserting my first conjunct I purportedly express my belief, via E1, that it is raining, yet I have also told you that I do not believe that it is raining. My reply is improper because I have purportedly-asserted-and-expressed a contradiction. This remains so even if my assertion is insincere, which explains why you still hear absurdity even after you learn that I am lying.

\section{Types of Assertion and Their Norms}

As we have seen, one way in which an assertion may be improper is that making it frustrates its point. Another way in which it may be improper, which may or may not coincide with the first way, is that one makes it as a type of assertion while failing to be in the epistemic state needed for it to be of that type. In this sense, the norm of a type of assertion is the epistemic state one needs for one's speech-act to succeed in being an assertion of that type. The epistemic state in question is determined by the point of the type of assertion.

We may describe this intended change as informing, or specifically, teaching or confessing, reporting belief or conviction, as in opining or proclaiming one's faith, reporting knowledge, as in answering an examiner, instilling disbelief, perhaps eristically, and as instilling false belief, as in lying.

For example, when my assertion to you that $p$ counts as letting you know that $p$, I myself know that $p$. So in intending to let you know (or equivalently, 
inform you), I must know the content of my assertion. This is the norm of informing. Here the knowledge account gets things right. It is a genuine criticism of one's would-be informant that she does not know what she has told one, for she is practically irrational in trying to do what she should see will not succeed, namely transmit to one knowledge that she does not possess. The same goes for reporting knowledge. I cannot let my examiner know that I know the answer unless I really do know it. It is a genuine criticism of one's examinee that she does not know the answer. Here too the knowledge account gets things right.

Next consider opining, in other words giving one's opinion. You ask me 'Do you think it will rain?' and I answer 'Yes'. Given that this counts as my qualified assertion that it will rain, you will not find it improper, even if you know that I do not know that it is raining. After all, I have appropriately given you what you have asked for, which is not my knowledge of the weather but only my opinion. But if instead, I answer 'Yes but I don't believe that it will', then you hear absurdity. I cannot succeed in giving you my opinion that it will rain unless I believe that it will. So in intending to opine, I must believe the content of my assertion, otherwise I am practically irrational. This is the norm of opining. Here the knowledge account gets things wrong.

Next consider eristic assertion. In asserting to one's interlocutor that $p$, one cannot sensibly or appropriately aim to 'wind her up' by making her think mistakenly that one disagrees with her in her belief that not- $p$ unless one believes that she believes that not- $p$. This is the norm of eristic assertion. But this does not mean that one knows that $p$. So here again the knowledge account gets things wrong.

Lastly, consider lying. The point of one's lie is to make one's interlocutor mistakenly believe that its content is true. One attempts to do so by purporting to express belief or knowledge of the content of the lie, in other words by offering her defeasible reason to think that one believes or knows its content. Purporting to express knowledge of it, for example by telling the lie emphatically, is more likely to result in the success of the lie than purporting to express belief in its content. This is because if she comes to think that one knows, rather just believes, its content, then she has more reason to believe it as well. But of course this does not mean that the norm of lying is that one believes or knows its content. Its norm is rather that one believes that its content is false. For however one tells a lie that $p$, one cannot aim to make one's interlocutor mistakenly believe that $p$ via one's assertion that $p$ unless one 
believes that not- $p$. To appreciate this point, suppose you enlist my rational cooperation in getting me to lie to someone that it is $2 \mathrm{pm}$. I tell her 'It is $2 \mathrm{pm}$ ' and then whisper to you the aside 'but I don't believe that it is not 2 pm'. You will find this improper, because you will recognize that if my aside is sincere then I have failed to tell a lie. At best I would have made my assertion on the basis of a guess. From your perspective, in whispering the aside I have broken a rule of lying. You might say that I have 'cheated'. Here again the knowledge account gets things wrong.

\section{Concluding Remarks}

I submit that my account of norms of assertion coheres well with the idea that assertions are akin to types of game with different rules and with the indisputable fact that there are types of bona fide assertion other than informing. It clearly locates the source of criticism arising from violating a norm of a given type of assertion as a form of practical irrationality and it provides a plausible analysis of the speech-act of assertion, one that explains the propriety or otherwise of assertions.

\section{References}

BALDWIN, T. G.E. Moore. London: Routledge, 1990.

Benton, M. A. Two More for the Knowledge Account of Assertion. Analysis 71: $684-687,2011$.

Assertion, Knowledge and Predictions. Analysis 72: 102-105, 2012.

BlauUw, M. Reinforcing the Knowledge Account of Assertion. Analysis 72: 105-108, 2012.

Brown, J. Knowledge and Assertion. Philosophy and Phenomenological Research 81: 549-566, 2010.

Cappelen, H. Against Assertion. In Assertion: New Philosophical Essays. Eds, J. Brown and H. Cappelen. Oxford: Oxford University Press. 21-48, 2011. 
DeRose, K. 2002. Assertion, Knowledge, and Context. Philosophical Review 111:167-203.

Douven, I. Assertion, Knowledge, and Rational Credibility. The Philosophical Review , 115: 449-485, 2006.

GrICE, H. P.Studies in the Way of Words. Cambridge, Mass.: Harvard University Press, 1989.

Hill, S. and SCHECHTER, J. Hawthorne's Lottery Puzzle and the Nature of Belief. Philosophical Issues 17: 102-122, 2007.

Jones, O. R. Moore's Paradox, Assertion and Knowledge. Analysis 51: 183186, 1991.

Kvanvig, J. L. Assertion, Knowledge, and Lotteries. In Williamson on Knowledge. Eds. , 2009

D. Pritchard and P. Greenough: Oxford: Oxford University Press. 140160, 2009.

LACKEY, J. Norms of Assertion. Nous 41: 594-623, 2007.

Learning from Words. Oxford: Oxford University Press, 2008.

LUTHER, M. D. Martin Luther's Werke: kritische Gesamtausgabe (Weimarer Ausgabe). Weimar: H. Böhlau, 1883.

Maitra I, and Weatherson, B. Assertion, Knowledge and Action. Philosophical Studies 149: 99-118, 2010.

MCKINNON R. and TURRI J. Irksome Assertions. Philosophical Studies 166: 123 128, 2013.

MoOre, G. E. A Reply to My Critics. In P. Schilpp (Ed.), The Philosophy of G.E., Moore. Evanston: Northwestern University Press. 535-667, 1942.

Russell's Theory of Descriptions. In P. Schilpp (Ed.), The Philosophy of Bertrand Russell. La Salle, Ill: Open Court. 175-225, 1944.

Commonplace Book: 1919-1953. London: George Allen \& Unwin, 1962.

Rosenthal, D. Self-knowledge and Moore's Paradox. Philosophical Studies 77: 195-209, 1995. 
Expressing One's Mind. Acta Analytica 25: 21-34, 2010.

SLOTE, M. A. Assertion and Belief. In J. Dancy (Ed.), Papers on Language and Logic,. Keele: Keele University Library. 177-190, 1979.

SORENSEN, R. A. 1988. Blindspots. Oxford: Clarendon Press.

TURRI, J. Prompting Challenges. Analysis 70: 456-462, 2010.

The Express Knowledge Account of Assertion. Australasian Journal of Pbilosophy 89: 37-45, 2011.

Knowledge and the Norm of Assertion: A Simple Test. Synthese 192: 385 - 392, 2015.

Unger, P. Ignorance: The Case for Skepticism. Oxford: Clarendon Press, 1975.

WeIner, M. Must We Know What We Say? Philosophical Review 114: 227-51, 2005.

Welbourne, M. More on Moore. Analysis 52: 237-241, 1992.

Williams, J. N. Moore's Paradox - One or Two? Analysis 39: 141-2, 1979.

Moorean Absurdity and the Intentional 'Structure' of Assertion. Analysis 54: 160-66, 1994.

Moore's Paradox, Defective Interpretation, Justified Belief and Conscious Belief. Theoria 76: 211-248, 2010.

Moore's Paradox and the Priority of Belief Thesis. Philosophical Studies 165: 1117-1138, 2013.

Not Knowing You Know: A New Objection to the Defeasibility Theory of Knowledge' Analysis 75: 213-217, 2015.

Williamson, T. Knowledge and Its Limits. Oxford: Oxford University Press, 2000.

WitTGenstein, L. Remarks on the Philosophy of Psychology volume 2. G.H.

VON WRIGHT and H. HYMAN (eds.). University of Chicago Press, Chicago, 1980. 